Sanrachna

\title{
The Dietary Trend In The World Particularly In China And India
}

\author{
Kiran Yadav
}

\begin{abstract}
Objective: Evaluate the trend of dietary convergence in the world. How specifically do Indian and Chinese diets have changed and middle-class consumption and evaluate their dietary trend?
\end{abstract}

Methodology: The paper analyses the diet patter of India and China from 1990 to 2019. The paper is particularly keen to analyse the impact of income, urbanization and proportion of the young population on diet pattern. The data of food balance for these two countries is taken from FAOSTAT. To measure the income effect, the GNP per capita data is taken from World Bank. The population and urbanization data is taken from UN world population prospects 2019 and UN world urbanization prospects 2018. The linear regression model is used to analyse the impact of socio-economic factors.

Results: The analysis has found that rise in income is positively associated with the macronutrients diet for Indians particularly for carbohydrates consumption whereas for Chinese the reverse is true. The study found that urbanization of the population is highly positively associated with the consumption of carbohydrates diet for Chinese whereas, for India, urbanization is negatively associated with fat consumption. The change in young age population negatively impacts the fat consumption for China while positively impact the consumption of carbohydrates for Indians.

Conclusion: The gap between dietary pattern is found to be reduced globally. Consumption of many food groups shows convergence for a different region. The consumption of macronutrients between India and China from 1990 to 2019 shows the converging trend in the early 1990s but after that, it shows divergence. In both countries, socio-economic factors push more toward carbohydrates diets.

Keywords: Diet, Urbanization, Income, Nutrition transition, Macronutrients, Food groups

\section{Introduction}

The changes in lifestyle and less awareness over the nutrition-related non-communicable disease such as diabetes is the main reason that we should focus on dietary pattern across the globe. The hectic work schedule, lack of exercise etc. becomes an important reason for changing food consumption patterns such as more takeaways and more ready to eat foods consumption. In recent time with the cases of meat consumption related disease, many countries are also looking into the growing scope of faux meat. All this leads to an increase in interest in food diets such as sugar-free, organic food, pro-biotic food, and vegan foods. However, with the rapid urbanisation, economic growth and changing demographic factors, we have seen the changing patterns of food consumption across the countries over a different time 


\section{Sanrachna}

period. To deal with the growing diet-related disease we need to understand the changes in diet pattern and different socio-economic factors that affect it.

In this paper, we try to find out the trend of diet in the world and more precisely in the case of India and China. Does the change in lifestyle or different socio-economic factors change the diet pattern in these two countries? We try to find out the changes in dietary trend in these two countries over the past decade and if there is then how does this change occur and is there any convergence or not between these two countries diet pattern. These two countries are chosen because of their some similarities and dissimilarities in socio-economic factors and dietary pattern. Such as both are developing nations with similar geography along with that both are the largest countries with the highest population. In both countries, rice is a staple food but dissimilarities occur in meat consumption. Apart from rice, in China meat consumption is high especially pork meat whereas India's food consumption is majorly based on wheat and pulses.

\section{Diet trends across the globe}

The changes in food consumption pattern have been found all across the world from the 1960s to 2000s. In some cases, the changes are converging while in some other it is diverging. The study from FAO on global and regional food consumption pattern is also confirming that. The study from FAO shows that the supply of vegetables per capita between 1970 and 2000, is converging for Europe, low-income food-deficit countries, and developing countries with an average world supply of vegetables. The study also illustrates the share of dietary energy derived from cereals is relatively stable globally and in industrialized countries, however, it is decreasing in the case of developing countries and the pattern is expected to decline by over 2030. This shows that in developing countries, cereals becoming less popular food.

\section{Figure 1: Per capita meat consumption (kg/year) for different regions}

\section{Per Capita Meat Consumption}

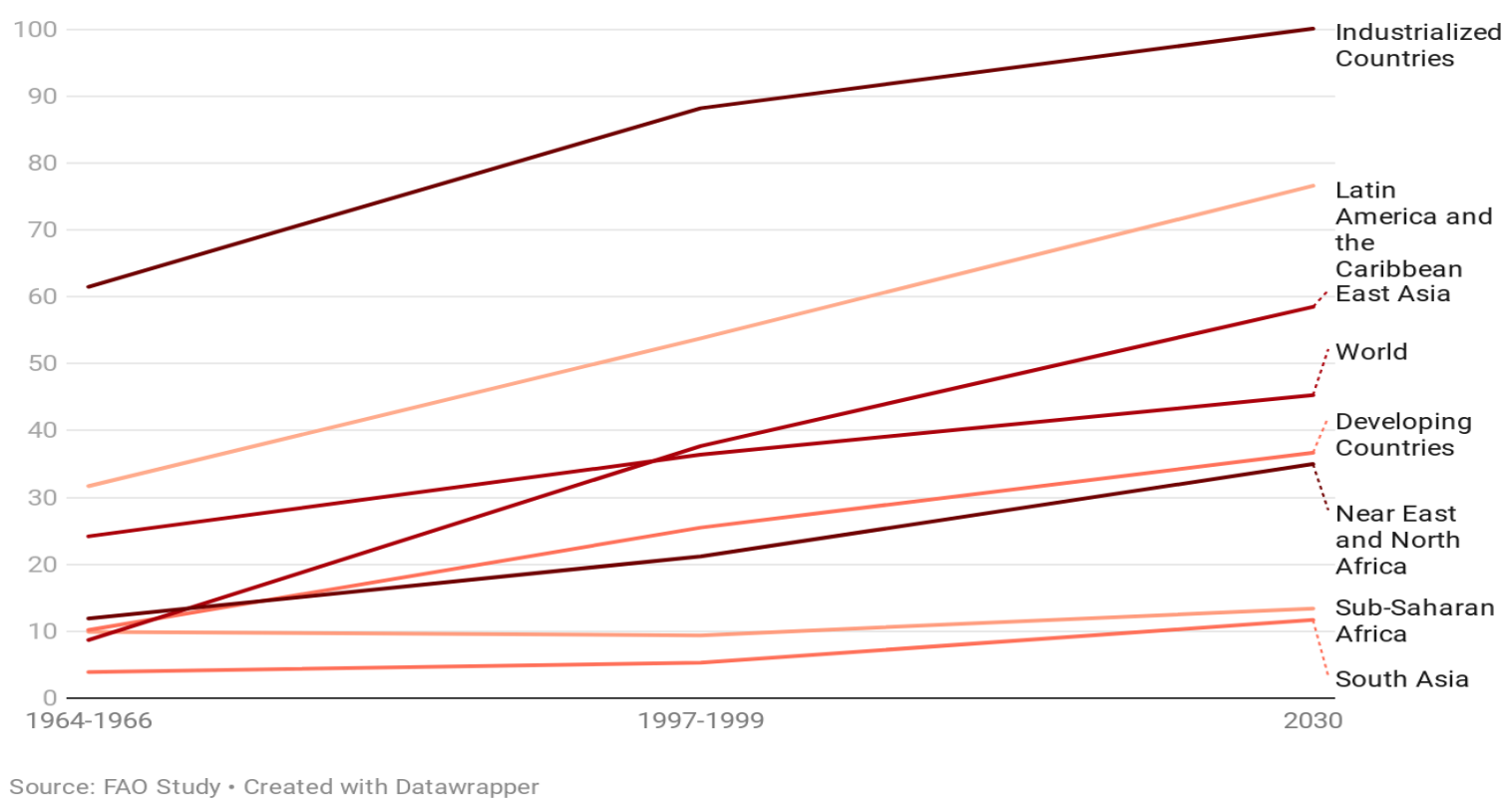




\section{Sanrachna}

As for meat consumption, the above figure shows that Sub-Saharan Africa and South Asian countries are expected to converge the meat consumption by 2030. Similarly, East Asian countries meat consumption per year is approximately the same with the average world consumption for the year 1997-99 but after that, the trend is expected to diverge by the year 2030. Besides, the meat consumption for industrialised countries is highest among all.

Figure 2: Per capita milk consumption (kg/year) for different regions

\section{Per Capita Milk Consumption}

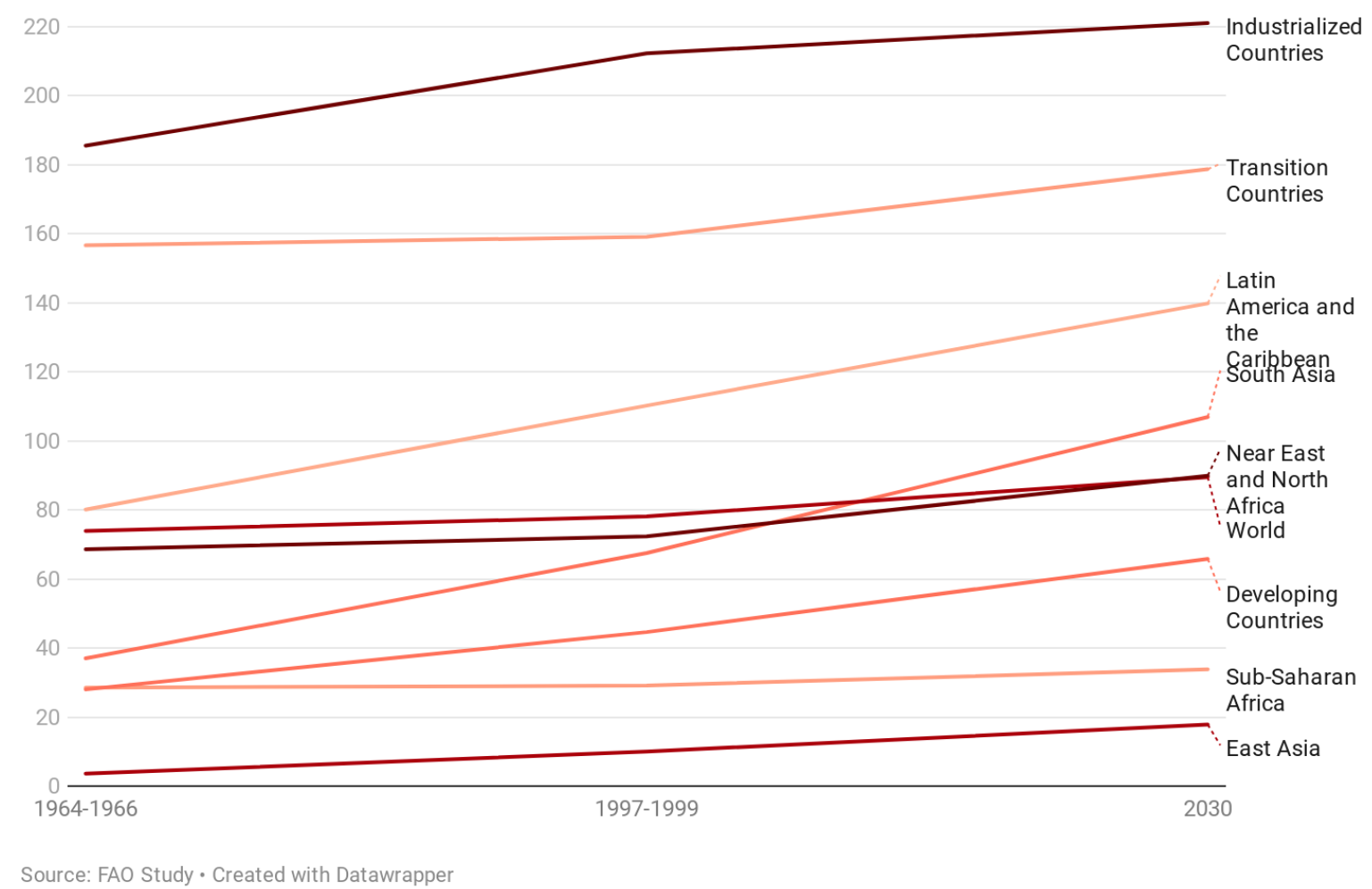

The milk consumption for the South Asian, and Near East \& North Africa is close to the average world milk consumption in 1997-99 but after that, the milk consumption in South Asia is expected to grow higher than Near East \& North Africa. Though milk consumption is high in industrialised countries, the trend shows that per capita milk consumption in transitional countries is expected to grow faster than industrialised countries and the gap between these two types of countries is expected to reduce. 


\section{Sanrachna}

Figure 3: Trends in the dietary supply of fat for different regions

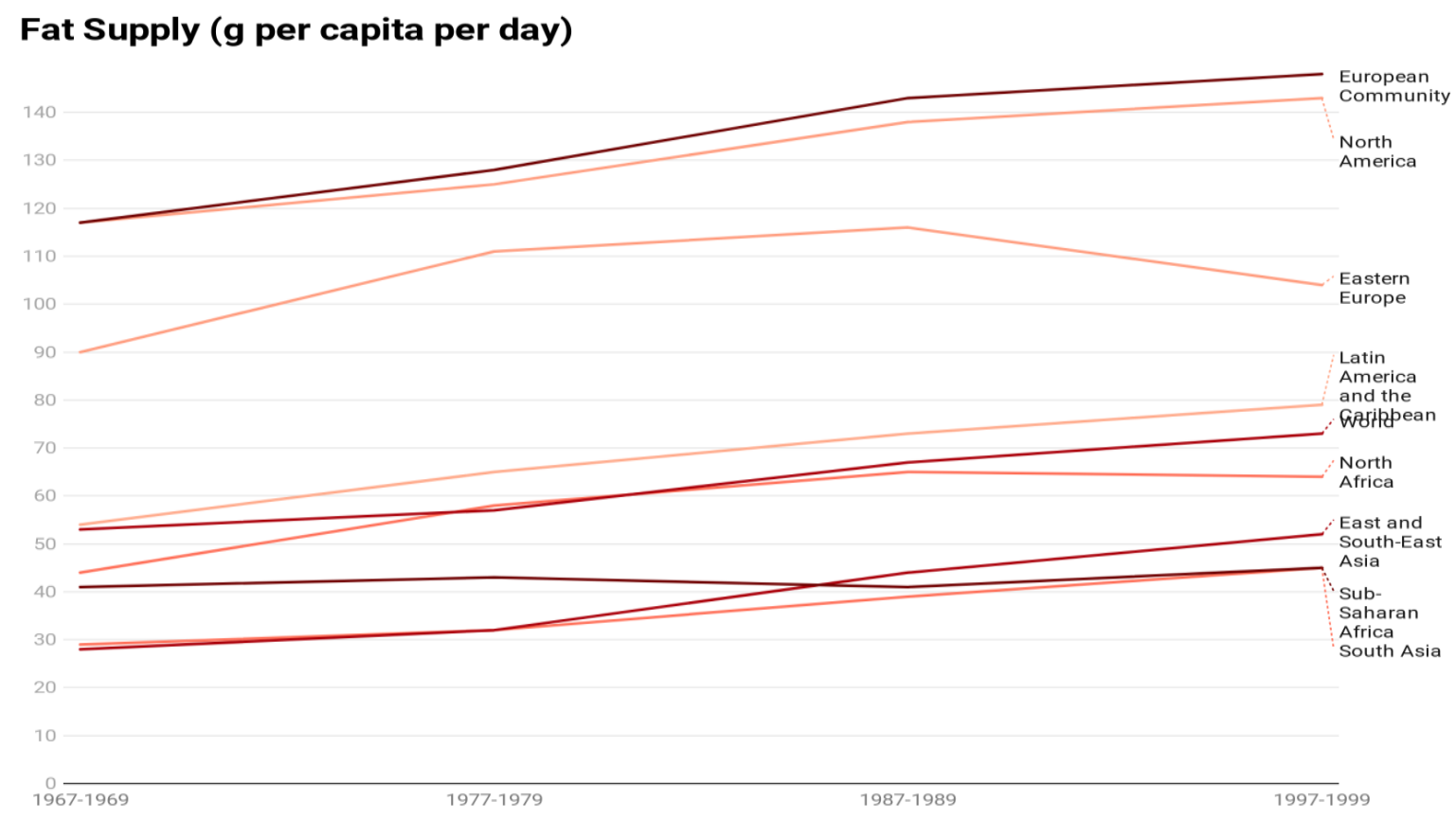

Source: FAO Study , Created with Datawrapper

Except for Eastern Europe, the fat supply is increased worldwide since 1967-69. The above figure shows that till 1979 the fat supply is approximately same for South Asia, and East \& South-East Asia however, after that the fat supply in East \& South-East Asia grows higher than South Asia counterpart. A similar trend is also showing for European Community and North America.

\section{Figure 4: Per capita Calorie Supply for different regions}

\section{Calorie Supply}

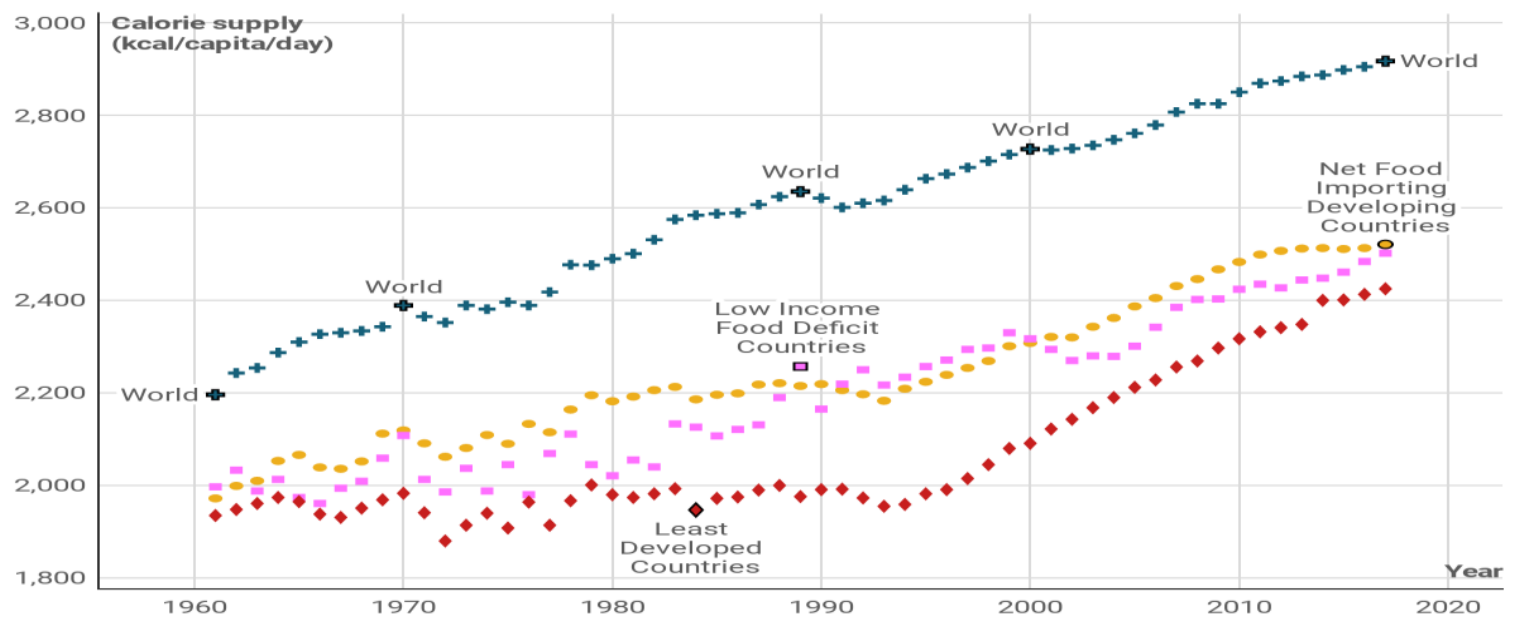

Source: FAOSTAT * Created with Datawrapper 


\section{Sanrachna}

The above graph is showing that the least developed countries, low-income food deficit countries and net food importing developing countries are converging in terms of calorie supply per capita per day.

\section{Figure 5: Per capita Protein supply for different regions}

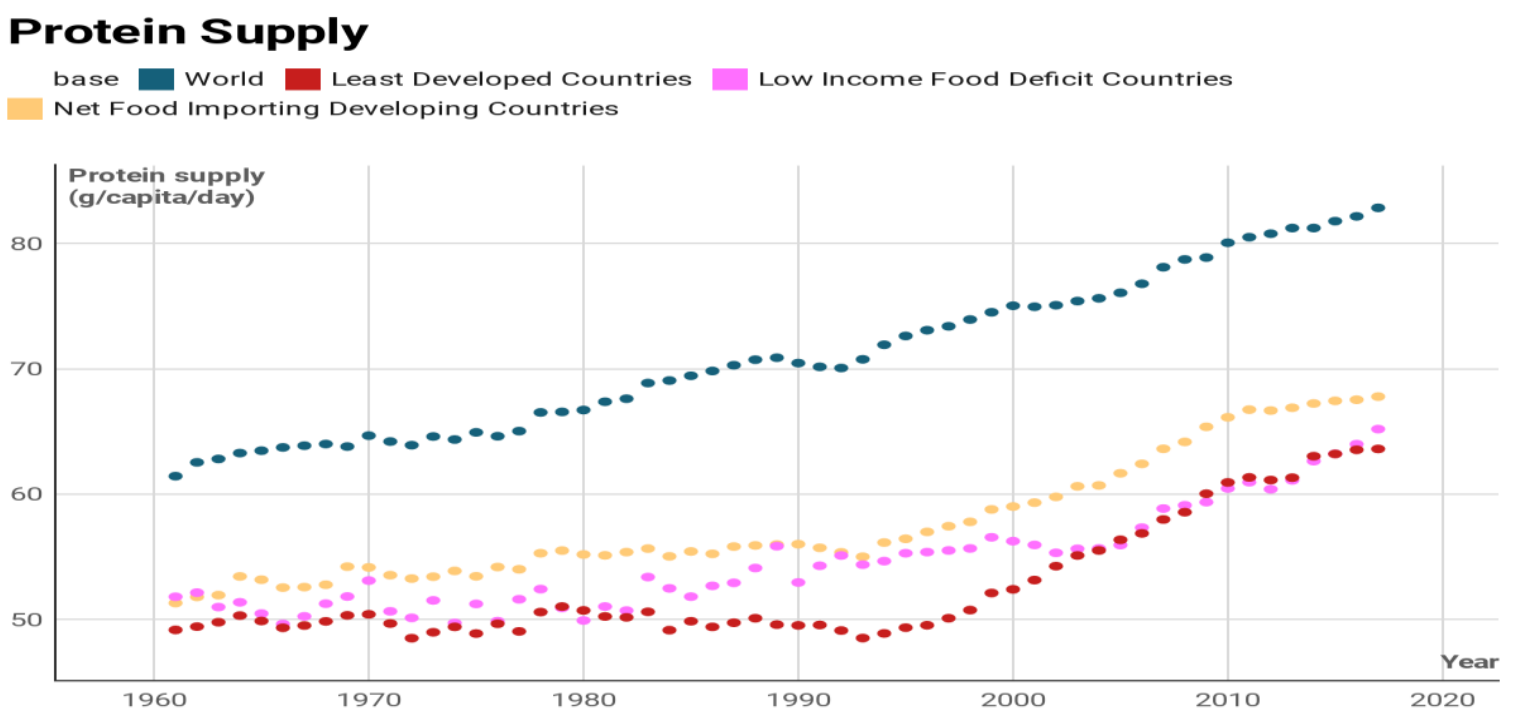

Source: FAOSTAT • Created with Datawrapper

The above graph of protein supply indicates that low-income food deficit countries and least developed countries have converged while net food importing developing countries are in a way to converge in terms of protein supply per capita per day.

\section{The diets trends in India and China}

In the late $19^{\text {th }}$ and early $20^{\text {th }}$ centuries, the middle class in China was in its initial stage due to the lack of well-established capitalism and the absence of independent entrepreneurship as an economic system. In the early 1980s when the opportunities for the private enterprise and profit were opened up by the leader of China, the middle class began to rise. It was at the end of the $20^{\text {th }}$ century when the middle class was officially recognised in China (Morreale, 2018). The growing middle class in the $21^{\text {st }}$ century was the main driver of FDI and local business in China. As the market in China opened up and private enterprise and local business rise up, it affected the people's diet pattern as noted by the decrease consumption of grain but an increase in fat intake among Chinese. In China, rice is a major staple food. Chinese people consume all animal's meat but the share of pork consumption is highest among them.

The economic reform of 1991 has given rise to a huge middle class in India as the country moving toward a market-led capitalist economy. Like in China, the primary factor of growth of the middle class is the incentivization of private capital investment and opening the economy to foreign investments. In the 1990s the approximate population of the middle class is 30 million in India that is less than $1 \%$ of the population which rises to about $5 \%$ of the population in 2004. This raises the middle-class consumption in India and after the USA and China, it is the third-largest middle-class market in the world (Roy, 2018). The food consumption pattern is very diversified in India. The north-east and south region of the country has rice as staple 


\section{Sanrachna}

food whereas the northern region has wheat as a staple food. In India, other than rice and wheat, cereals are also a major part of food consumption. India is considered as largely a vegetarian country, however, SRS survey shows that $71 \%$ of the Indian population is non-vegetarian while only $28.5 \%$ is vegetarian. Though a large population is non-vegetarian in India the highest share of this population is found in the southern and eastern region of the country. It is also true that meat consumption in India is very low as compare to other countries with only 0.5 , $0.2,2.4$, and $0.5 \mathrm{~kg} / \mathrm{capita}$ for beef and veal, pork meat, poultry meat and sheep meat respectively for 2018 (OECD data).

Figure 6: Calorie, Protein, and Fat consumption per capita per day comparison between China and India from 1960 to 2010 , food group wise.
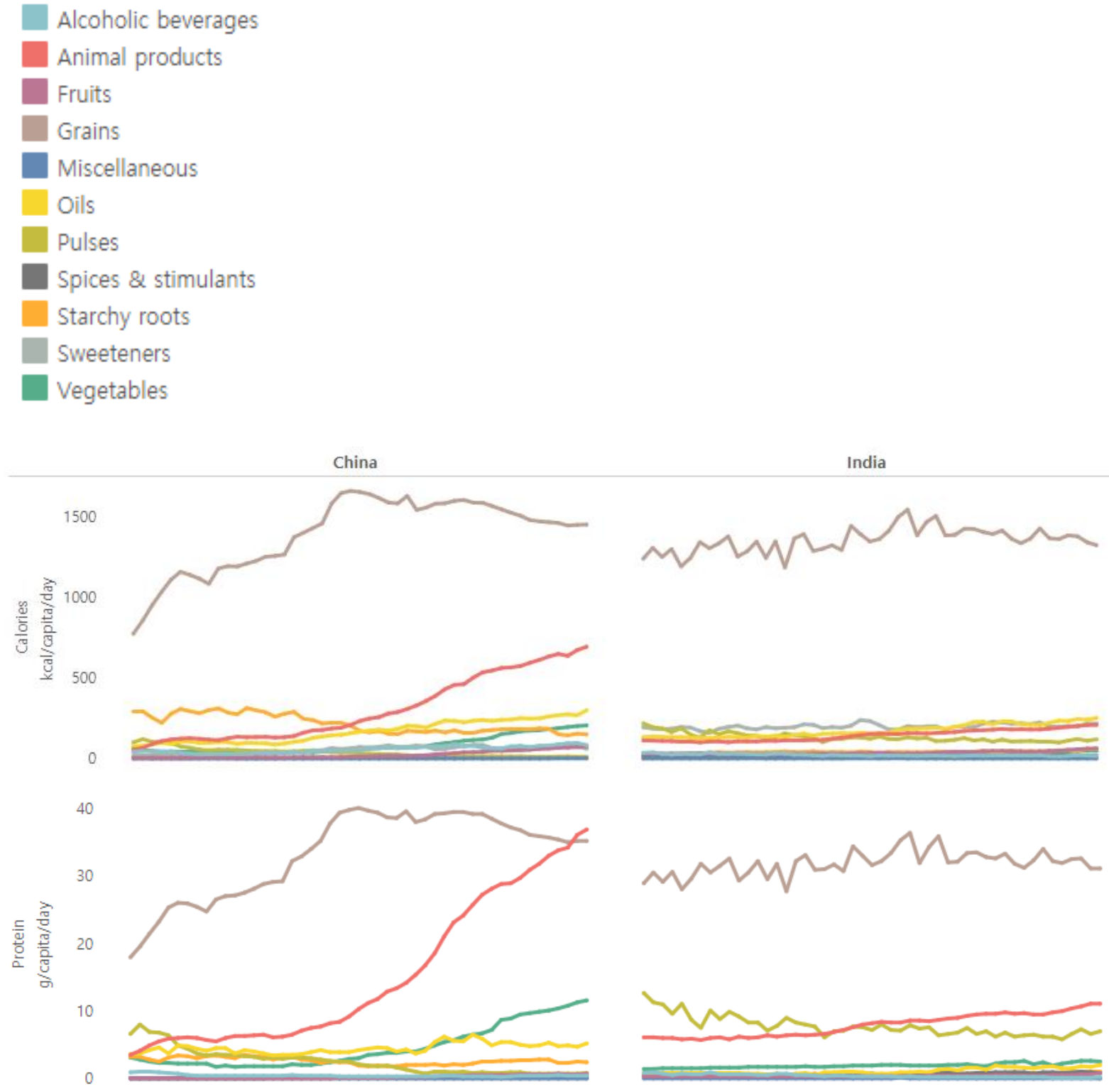


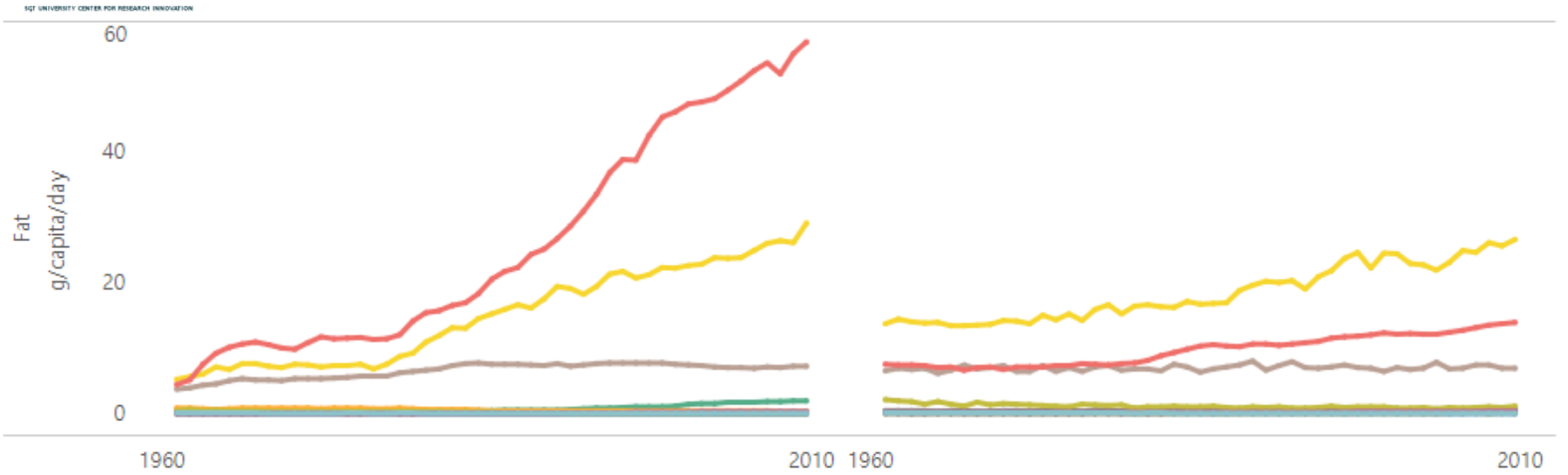

Source: CIAT

The above graph shows the trend of macronutrients in China and India from 1960 to 2010. The calorie and protein intake from grain in China is initially increasing but from the late 1980s, it started to decline. However, the calorie and protein from animal products are continuously increasing. Apart from animal products, protein from vegetables is also increasing however, the share is not as high as animal products. The highest source of fat consumption in China has come from animal products which have a rapidly increasing trend. Fat from oil also shows an increasing trend in China. In the case of India, the calorie and protein intake from grain show very fluctuating trend whereas, calorie and protein intake from pulses show continuously decreasing trend. Though the calorie and protein from animal products intake do not high in India, still it is showing an increasing trend. In India, animal products are the second-highest source for fat after oil and the graph for fat from both oil and animal products is showing an upward trend. Overall the consumption of animal products and oil is increasing in both countries with different proportion. The consumption of grain started decreasing since the late 1980s in China whereas it has a fluctuating trend in the case of India.

\section{Factors affecting diet pattern}

Changes in the diet depend on multiple factors such as economic structure, transition in demographic factors, changes in lifestyle, culture, technological growth etc. In demographic change such as the growth of population, age, education level, and spatial distribution in the population plays an important role in deciding the pattern of food consumption. The rapid urbanization is the important determinant as it is observed that the food consumption of people living in urban areas is very distinct from their rural counterparts. Apart from urbanization, economic growth is also a key determinant of food consumption. The shift from low income to high income increases the purchasing power which makes many food baskets accessible. High income allows the person to consume that food which is not accessible before and hence affect diet and nutrition pattern. However, affordability of food basket also affected by the inflation rate and if the inflation rate is higher than the rise in income then it has reverse consequences also. Along with that the change in economic structure also affects diet pattern. The shift from agriculture sector to industrial or service sector is associated with nutrition transition as industrial production is mostly dominated by capital-intensive work whereas agriculture is mostly dominated by labour-intensive work. The occupational pattern of the 
Sanrachna

person also affects the requirement of diets. The high level of physical activity at work requires more energy.

\section{Literature Review}

A paper by Alice Yunzi et al. on the dietary trends in Chinese Adolescents (age 12-17 years) from 1911 to 2011, shows that Chinese adolescents are transitioning to low carbohydrate diet and urbanization play a role in sodium, potassium, and protein intake. The paper used the linear multivariable regression models over energy, micronutrients, sodium, and potassium by taking the data from survey years 1991, 2000, and 2011 from nine different provinces of China. The other study (Cui et al. 2012) focus on nutrition transition in children in China and used the China Health and Nutrition Survey (CHNS) from 1991 to 2009. The study used the mixedeffect model and found that there was a steady decline in daily energy intake, and daily carbohydrate intake. In contrast, the daily fat intake and proportion of energy from protein were steadily increased. The study shows rapid nutrition transition to high fat diet among Chinese children. The other study (Popkin, 2001) by using the CHNS data from 1989 to 1997 also confirmed a remarkable increase in obesity among Chinese adults. Another paper by (Xu et al. 2015) talked about the macronutrient intakes status of older Chinese people. The paper used the dietary intake data of 2746 older Chinese people from Longitudinal CHNS 2009 data. The study found that less than one-third of the older Chinese people met the adequate intake of carbohydrate and fat; less than one-fifth had an intake of recommended protein energy and more than half of older people had fat intake higher than recommended. The paper on dietary macronutrient intake among adults in rural China from 1991 to 2011 (Su et al. 2017) also confirm the downward trend in daily energy, protein, and carbohydrates intakes but significant rising trend in daily fat intake. The paper used CHNS data and the Chinese rural population aged 18-60 years by using the mixed-effect models. The paper by (Drewnowski and Popkin, 1997) talked about the nutrition trend in the global diet. The paper revealed the major shift in the structure of global diet mark by the classic relationship between income and fat. The analysis of 21 Asian nations during the period 1975-1994, shows a decline in the proportion of energy derived from carbohydrates and increase in the proportion of energy from fat particularly in the case of China. The paper predicted that China would experience the nutrition transition much sooner than other countries and this shift is associated with rapid urbanization, decrease in fertility, the decline in mortality and an increase in education. A paper on dietary fat intake in adults in urbanizing China ( $\mathrm{Su}$ et al, 2020) examined the relationship between urbanicity and fat intake in Chinese adults aged 18-65 from 1991 to 2015 by using a multilevel model. The result of the study indicates that urbanization was an important factor which influences the fat intake among Chinese adults. Another paper by (Zhao, 2018) focused on temporal trends of total energy and micronutrient intakes among Chinese adults females from CHNS, 1991-2015 longitudinal data by using mixed-effect models. The result of the analysis was a significant reduction in daily energy, protein and carbohydrates intakes among Chinese female adults. Whereas it was observed that daily fat intake, the proportion of energy from fat, and females consuming more than $30 \%$ of fat and less than $50 \%$ of carbohydrates were significantly increased. A paper by (Liu et al, 2018) emphasised on the association of dietary pattern with obesity of Chinese children in medium and small cities. The paper is a cross- 


\section{Sanrachna}

sectional study of children aged 6-17 years old in 2010-12 CHNS and talked about two dietary patterns i.e. westernized pattern and traditional Chinese pattern. The study found that westernized pattern was significantly associated with increased risk of obesity and positively correlated to household income, high energy intake and negatively correlated with age and housework time. The traditional Chinese pattern was positively correlated to energy intake, housework time, age and negatively correlated with household income and traffic tools. Another paper by (Huang et al, 2020) talked about nutrition transition in China. Using the data from CHNS, the paper observed significant changes in the structure of the diet among Chinese adults. The change was characterised by a decrease in the intake of cereals and vegetables and an increase in intakes of animal foods especially pork. Eggs, fish and dairy consumption remains low with an only small increase over time whereas salt and cooking oil consumption was far above the recommendations. Another study (Du et al, 2014) documented the nutrition transition in China in the duration of 1949-1992 period. The paper examined that diet pattern was shift greatly over this period, cereal consumption increased over this period which was already high, consumption of animal-source and energy intake from fat tripled, and that from carbohydrates decreased over the same period. Physical activity was high in all domains however, mechanization of work were beginning to occur. A prospective study on nutrition transition (Zhai et al, 2009) also confirmed the transformation of diet pattern in China. The study included 18-45 years from 4280 households in nine provinces of China. As per the study average consumption of all animal food except milk increased while cereals intake decreased. The energy from animal protein and fat was increased however, vitamin A and calcium intake remained low. The paper described economic reforms in China as a reason for this shift. Another paper by (Zhai et al, 2014) described the dramatically changed pattern of food consumption and cooking behaviour between 1991 and 2011. The paper also confirmed the shift toward fats, protein and sodium intake. There was a rapid decline in coarse grain, and later refined grains and increase in edible oils and animal source foods particularly pork but consumption of poultry and eggs was also increased. The shift in dietary pattern is greatly affected by China's urbanization and also changes in cooking and eating styles, increase in snacking, and eating away from home.

For India, though not many papers are available that exclusively focused on dietary trends, some papers talked about the relationship between dietary patterns and their impact on NCDs. One such paper is by (Mishra et al. 2011) which indicates that nutrition transition from 1973 to 2004 , resulted in a $7 \%$ decrease in carbohydrates-energy and 6\% increase in fat-energy. The paper also suggests that decreasing intake of coarse cereals, fruits, vegetables and pulses and lack of exercise leads to many non-communicable diseases in Indians. The other paper (Tak et al. 2019) used the household consumption survey data from 1993 to 2012 and found that Indian diets have shifted away from cereals toward milk by using k-mean cluster analysis with multivariate methods. The growth of consumption of fruits, vegetables, meat and egg has been low. By 2012, one-fifth of the rural households did not consume fruits and milk. However, the study found out that a large percentage of the population still, consumes cereals-focuses, dairyfocused, and highly processed food. Another paper by (Kaicker et. al. 2011) that examined the changes in diet from 1993 to 2004 confirmed the trend that diets in India have shifted away from cereals, toward higher consumption of fruits, vegetables, oils and livestock products. The paper used the household data from NSS and applied the regression analysis. The paper also 


\section{Sanrachna}

confirmed the significant impact of cross-price effects, income/expenditure effects and more sedentary lifestyles on the dietary pattern in India. A paper on future diets in India (Alae-Carew et al, 2019) based on evidence suggested that there was a projected increase in per capita consumption of vegetables, fruit, and dairy products. Little change was projected in case of consumption of cereal (rice and wheat) and pulse and meat consumption was projected to remain low in India. A paper by (Chaudhary et al, 2020) focus on unequal fruit and vegetable consumption in India from NSSO data, suggested that household income and price are important correlates but the consumption of fruits and vegetables are also higher where households are headed by women, involve agricultural livelihood or are rural. The paper also marked that caste was an important source of this inequality in consumption, and the evidence was also found that formal agricultural market infrastructure was positively associated with consumption of fruits and vegetables in India. A report by (Amarasinghe et al, 2007) projected that total calorie supply would continue to increase, however, the share of food grains in consumption basket would likely to be decreased and the consumption of non-grain crops and animal products would increase by 2050 . Although the study suggested a decrease in total food grain demand, the total grain demand would likely increase due to an increase in feed demand for livestock. Another study on projections for foodgrains demand (Kumar et al., 2009) estimated the demand for food grains for the year 2011-12, 2016-17, and 2021-22 by accounting various socio-economic factors. The study projected that there would be an increase in direct household demand for foodgrains and total domestic demand for food grains. The study also found that rise in per capita income, rapid urbanization, increasing employment opportunities for women causing a significant rise in home away demand for foodgrains. Another paper by (Popkin et al, 2001) on trends in diet, nutrition status in China and India also projected the cost of undernutrition and diet-related noncommunicable diseases in 1995 and 2025. The paper stated that in both countries the diet was shifting toward high fat and lower carbohydrates intake. However, the differences were high intake of animal source and edible oil in China, whereas, in India, there was a high intake of dairy and added sugar. The study found that a higher proportion of overweight is increasing rapidly among all Chinese adults, on the other hand, in India, this was found more among urban residents and high-income rural residents. A paper by (Minocha et al. 2019) emphasised on high quality protein foods in India by simulation method using nationally representative datasets, estimated that Indian diet expected to move towards greater demand for high quality protein food particularly for pulses and milk. However, the demand for eggs, fish and meat was not expected to rise significantly. The study by (Bowen et al, 2011) that focus on dietary intake and rural-urban migration in India, based on 6,509 participants, concluded that sugar, meat and dairy intake were found to be high in migrants and urban participants as compare to rural participants. The study observed that rural to urban migration positively associated with higher fruits and vegetable intake, and negatively associated with higher energy and fat intake. Another paper (Sharma et al. 2020) that compare Indian diet with EAT-lancet reference diet, used the consumption expenditure survey conducted by NSSO in 2011-12 with a sample of 0.102 million households. The paper suggested that the average daily calorie consumption was below in India than recommended except for the richest $5 \%$ of the population. The consumption of cereals found excessive among Indians while protein, fruits and vegetables, meats, fish, and eggs consumption were found to be significantly lower. The energy from protein was also found to be lower, this imbalance was 
Sanrachna

highest in poor households but lack of adequate consumption of fruits, vegetables, and noncereal proteins was also found in richest households in India.

\section{Data}

The data on the supply of macronutrient energy from protein, fat, and carbohydrates are taken from FAOSTAT ${ }^{1}$. The protein, fat and carbohydrates supply quantity are measured in the unit of $\mathrm{g} / \mathrm{capita}$ /day which gram per capita per day whereas the supply of energy is measured in kcal per capita per day. The data on food groups are also from FAOSTAT. The FAOSTAT data from 1990 to 2013 based on old food balance sheet methodology while preceding year data based on new food balance sheet methodology. The cereals group includes barley and products, maize and products, millets and products, oat, rice and products, rye and products, sorghum and products, wheat and product, and other cereals but exclude beer. Fruits include all types of fruits and plantains excluding wine. Sugar and Sweeteners include honey, raw sugar, sugar non-centrifugal, and other sweeteners. Vegetables include onions, tomatoes and products, and other vegetables. Milk consumption excludes butter while animal fat includes butter, ghee, cream, fish (body oil, liver oil), fats, raw animals. Vegetable oils include all the oil crops such as coconut oil, groundnut oil, palm oil, soyabean oil, sunflower oil, olive oil and so on. Pulses include beans and peas and other products while meat includes poultry meat, mutton, bovine meat, pork and other.

The GNI per capita data is from World Bank data and are based on the constant 2010 US dollar $^{2}$. The GNI is the aggregation of value added by all resident producers plus any net product tax which is not included in the valuation plus net receipts of primary income from abroad. The GNI per capita is the GNI divided by midyear population. The CPI data is from World Bank data with the base period of 2010. The data on urbanization i.e. the proportion of the urban population is taken from World Bank, World Urbanization Prospects 2018. The definition of urbanization is different for different countries and it is different for both India and China. However, here urban population refers to the people living in urban areas as defined by the national statistical office. The data on the proportion of the young population is from the OECD. The young population in the OECD shows as the percentage of the total population. Though there is no universally accepted definition of young age population, the different region may have their own specific definition of young population. However, as per OECD, the young population refers to those people aged less than 15 . To capture the education factor, gross secondary school enrolment (\%) is taken from World Bank data. As per the World Bank definition, gross secondary school enrolment ratio is the ratio of total enrolment (regardless of age) to the population of the age group that corresponds to secondary education.

\section{Methodology}

\footnotetext{
${ }^{1}$ The data for supply of carbohydrates energy is derived from food supply energy by using energy conversion factors. http://www.fao.org/3/Y5022E/y5022e04.htm

2 The dataset is acquired for both India and China, however, it should be note that the data from World Bank and FAOSTAT for China do not include data for Hong Kong SAR, China; Macao SAR, China; or Taiwan China.
} 


\section{Sanrachna}

The trend of macronutrients and food availability in China and India is analysed during the period (1990-2019) All the data is analysed using Stata statistical software package version 13. For the statistical analysis, STATA 13 is used. The two-tailed p-value of less than 0.05 is considered statistically significant. GNI per capita, the proportion of the urban population and the young population, CPI, and secondary enrolment ratio are explanatory variables while macronutrient variables such as energy from protein, fat, and carbohydrates are response variables. The average income in China is 3736 US dollar, with a range from 1209 US dollar to 7778 US dollar with a standard deviation of 2120 US dollar. Around $42 \%$ of the average population living in urban areas. Average $22 \%$ of the population are young population in China. The average inflation rate is 88 . Approximately $60 \%$ of students enrolled in secondary education in China with a range of $36 \%$ to $88 \%$. The average supply of energy from protein, fat, and carbohydrates are $85 \mathrm{~g}, 79 \mathrm{~g}$, and $674 \mathrm{~g}$ with a standard deviation of 11,14 , and 49 respectively. On the other hand, the average income in India is 1128 US dollar, with a range from 567 US dollar to 2145 US dollar and a standard deviation of 480 US dollar. Average $29 \%$ population live in urban areas. Average $33 \%$ of the population are young population in India. The average inflation rate is 81 . Approximately $57 \%$ of students enrolled in secondary education in India with a range of $43 \%$ to $75 \%$. The average supply of energy from protein, fat, and carbohydrates are $57 \mathrm{~g}, 47 \mathrm{~g}$, and $565 \mathrm{~g}$ with a standard deviation of 3,5 , and 18 respectively. To better understand the nature of the variables, take a look at below graph of explanatory variables.

\section{Figure 7: Percentage of Secondary school enrolment (Gross)}

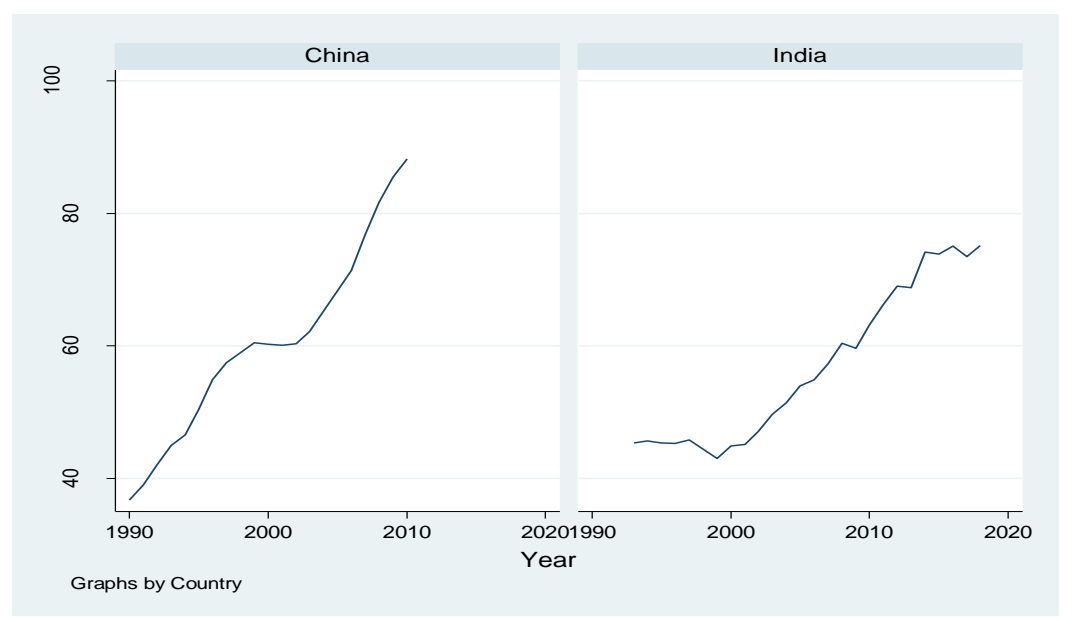

The gross enrollment ratio in secondary education is increasing in both countries however, the rate is higher in China as compared to India.

\section{Figure 8: GNI and CPI for China and India}




\section{Sanrachna}

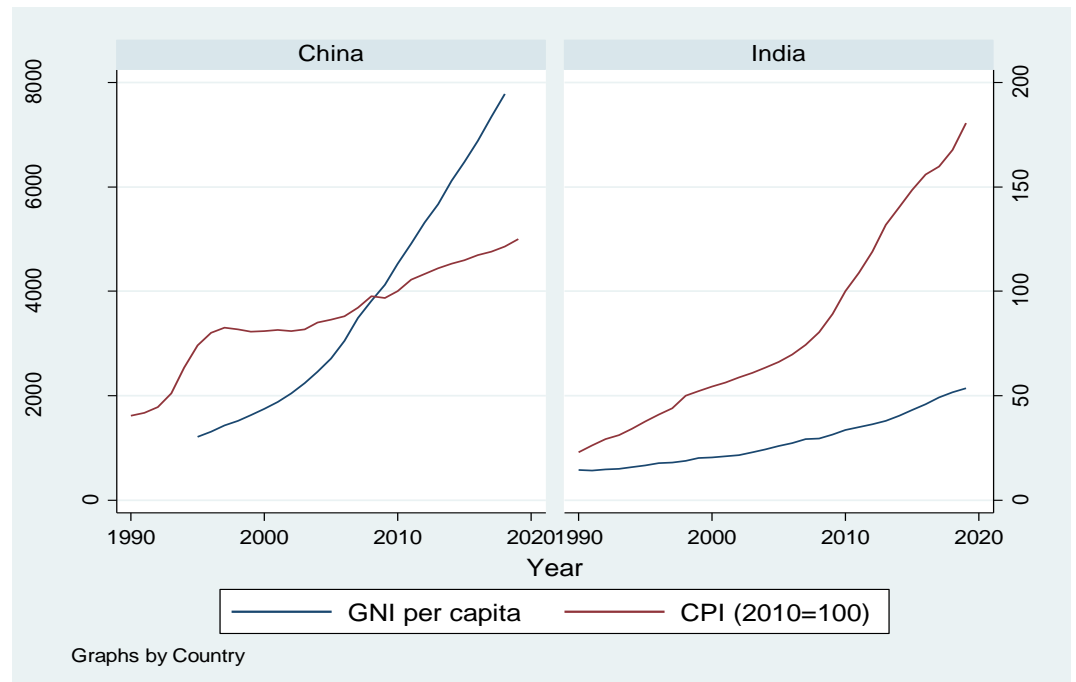

In China, the growth rate of GNI per capita is higher than the CPI means income rises faster than inflation, whereas, in India, the growth in inflation is higher than in GNI per capita.

\section{Figure 9: Proportion of urban population for India and China}

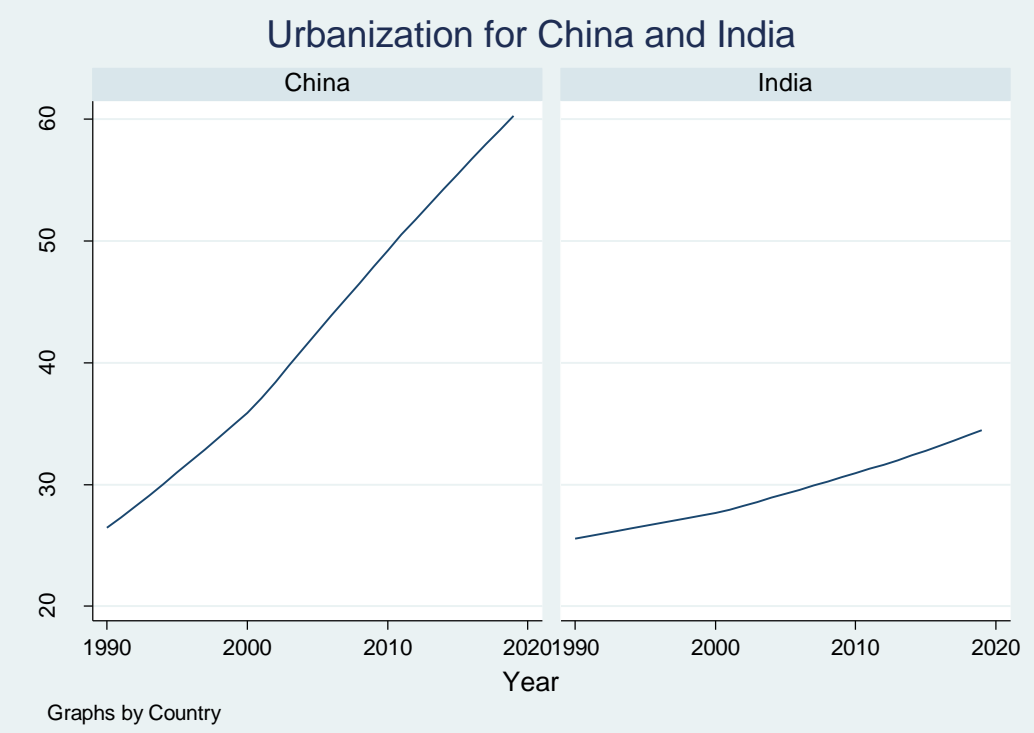

In both countries, urbanization follows the same patterns as GNI per capita, however, in China the pace of urbanization is very fast.

Figure 10: Proportion of young population for India and China 


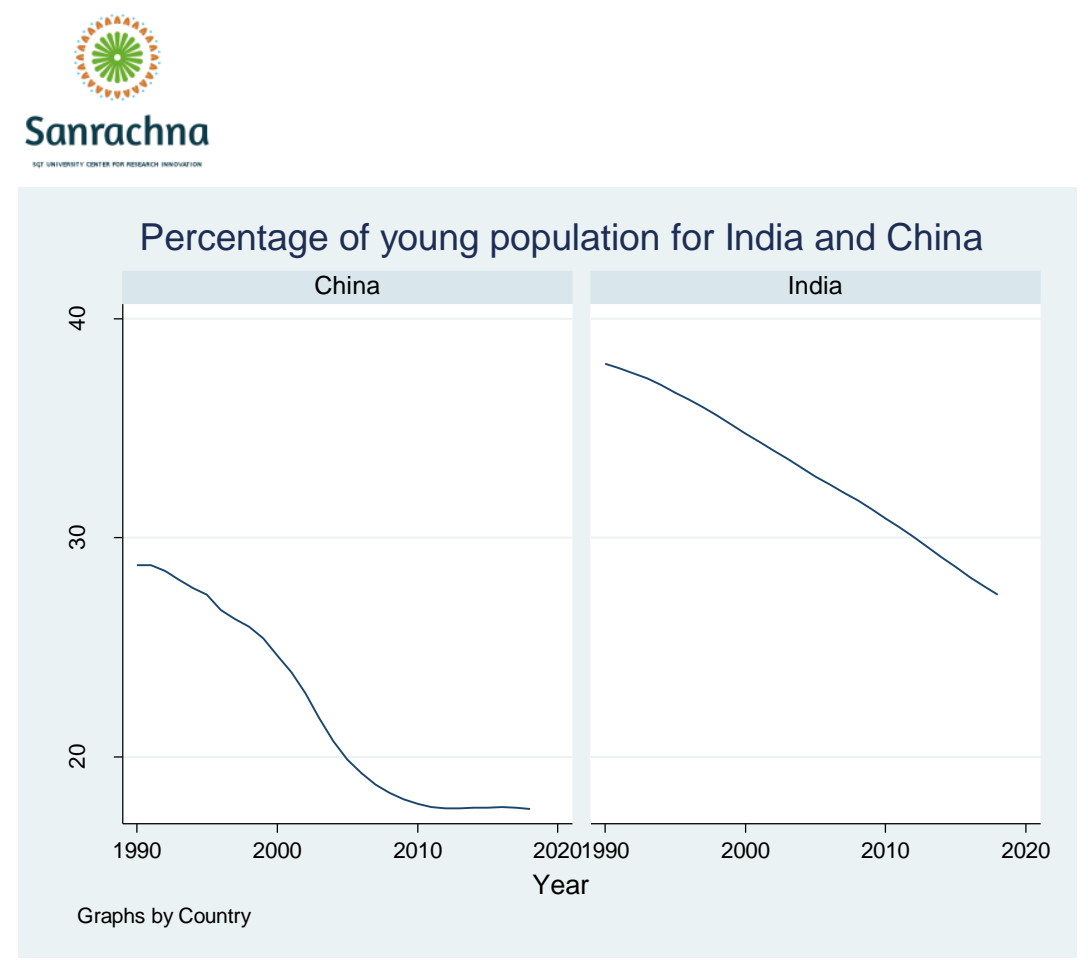

The young age population is decreasing in both countries, however, in China, the young age population decreases at a decreasing rate for the initial period. Between 2000 and 2010 it decreases at an increasing rate, the rate of decreasing is quite constant since 2010, whereas in India, the decrease in young age population is relatively stable.

To understand the impact of explanatory variables on response variables, the linear regression equation is used. The coefficient of log GNP represents the change in average consumption of protein, fat, and carbohydrates due to one percent change in GNP for the respective country. The coefficients of the urban population and young population represent the change in average consumption of macronutrients due to one unit change in the respective explanatory variable for the respective country. The constant term captures the impact of culture, taste and preference in India and China. The below regression table is free from heteroscedasticity and autocorrelation. Of course, there has been found multicollinearity among the variables as the explanatory variables are linked to each other especially with income. However, the analysis has found that the CPI and proportion of secondary education enrolment have an impact on our main explanatory variable which is income, urbanization, and proportion of the young population. As due to multicollinearity, the inclusion of both variables into our model changes the significance of our main explanatory variables. To fit the model and reduce the multicollinearity, the variable of the proportion of secondary education enrolment and CPI for all macronutrients energy is dropped since the transformation of the variable is also not very helpful in this case. However, it should be noted that the influence of CPI and percentage of secondary school enrolment on other variables are found to be higher in case of China whereas, in case of India, CPI is not as much influencer as in China.

Table 1 of the regression results

\begin{tabular}{|c|c|c|}
\hline Variables & China & India \\
\hline \multicolumn{2}{|c|}{ Protein } \\
\hline
\end{tabular}


Sanrachna

\begin{tabular}{|c|c|c|}
\hline Log of GNI per capita & $-19.471^{*}$ & $\begin{array}{c}19.797 \\
(2.854)\end{array}$ \\
& $2.123^{*}$ & $7.132^{*}$ \\
\hline Urban Population & $(.201)$ & $(1.785)$ \\
\hline Young Population & -.332 & $7.202^{*}$ \\
& $(.218)$ & $(1.568)$ \\
\hline Constant & $158.857^{*}$ & $-526.009^{*}$ \\
& $(17.396)$ & $(127.438)$ \\
\hline \multicolumn{3}{|c|}{ Fat } \\
\hline Log of GNI per capita & $-13.963^{*}$ & $66.493^{*}$ \\
& $(1.988)$ & $(10.582)$ \\
\hline Urban Population & $1.638^{*}$ & $-2.608^{*}$ \\
& $(.168)$ & $(.798)$ \\
\hline Young Population & $-1.497^{*}$ & $4.578^{*}$ \\
& $(.279)$ & $-487.527^{*}$ \\
\hline Constant & $155.507^{*}$ & $(113.453)$ \\
\hline \multicolumn{2}{|c|}{ Carbohydrates } \\
\hline Log of GNI per capita & $-74.065^{*}$ & $256.354^{*}$ \\
& $(20.352)$ & $(106.411)$ \\
\hline Urban Population & $9.592^{*}$ & 16.925 \\
& $(1.386)$ & $(13.43)$ \\
\hline Young Population & .787 & $39.731^{*}$ \\
& $(1.052)$ & $(13.284)$ \\
\hline Constant & $845.777^{*}$ & $-3015.768^{*}$ \\
& $(116.107)$ & $(1113.5)$ \\
\hline
\end{tabular}

Numbers in parenthesis are robustly standard error, * statistically significant at $95 \%$ level

The above regression table shows that a percentage change in income has a significant negative impact on the average consumption of all macronutrients for China however, this impact is far higher for carbohydrates. A unit change in the population living in urban areas in China has a significant positive impact on the average consumption of all macronutrients though, it will increase average consumption of fat by only 1.63 units, the average consumption of carbohydrates will increase by 9.52 units. A unit change in young age population of China has a positive impact on the average consumption of carbohydrates while the negative impact on average consumption of protein and fat however it is not statistically significant for carbohydrates and protein.

In the case of India, the income elasticity is found to be positively associated with the average consumption of all macronutrients. However, the percentage change in income has a limited impact on the average consumption of protein whereas it has a high impact on the average consumption of carbohydrates. A unit change in the population living in cities/urban areas in India has a positive impact on average consumption of protein and carbohydrates but harms average consumption of fat although it is not statistically significant for carbohydrates. A unit change in young age population of India has a significant positive impact on the average consumption of all macronutrients but has the highest impact on carbohydrates. 


\section{Sanrachna}

\section{Results}

The analysis has found that rise in income is positively associated with the macronutrients diet for Indians particularly for carbohydrates consumption whereas for Chinese the reverse is true. In the case of China, the income elasticity is negative for all macronutrients which can be explain by the fact that China's population is continuously decreasing due to which the overall food demand is decreasing while the income is rapidly increasing due to which income impact is showing negative. The study also found that urbanization of the population is highly positively associated with the consumption of carbohydrates diet for Chinese whereas, for India, urbanization is negatively associated with fat consumption. The change in young age population negatively impacts the fat consumption for China while positively impact the consumption of carbohydrates for Indians.

Figure 11: Energy from a protein supply, fat supply, and carbohydrates supply for China and India

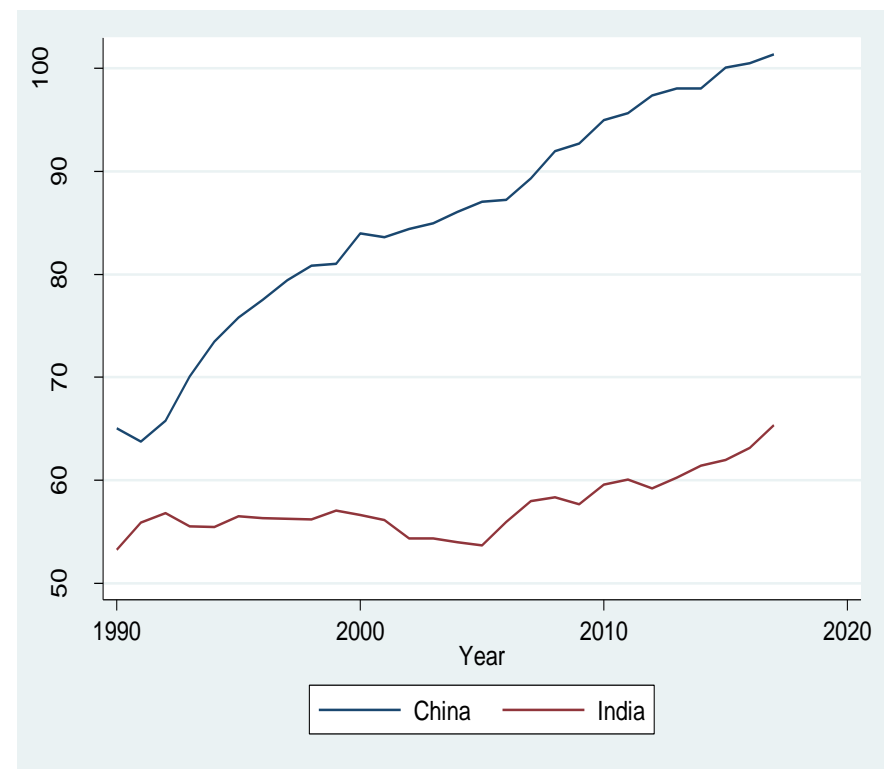



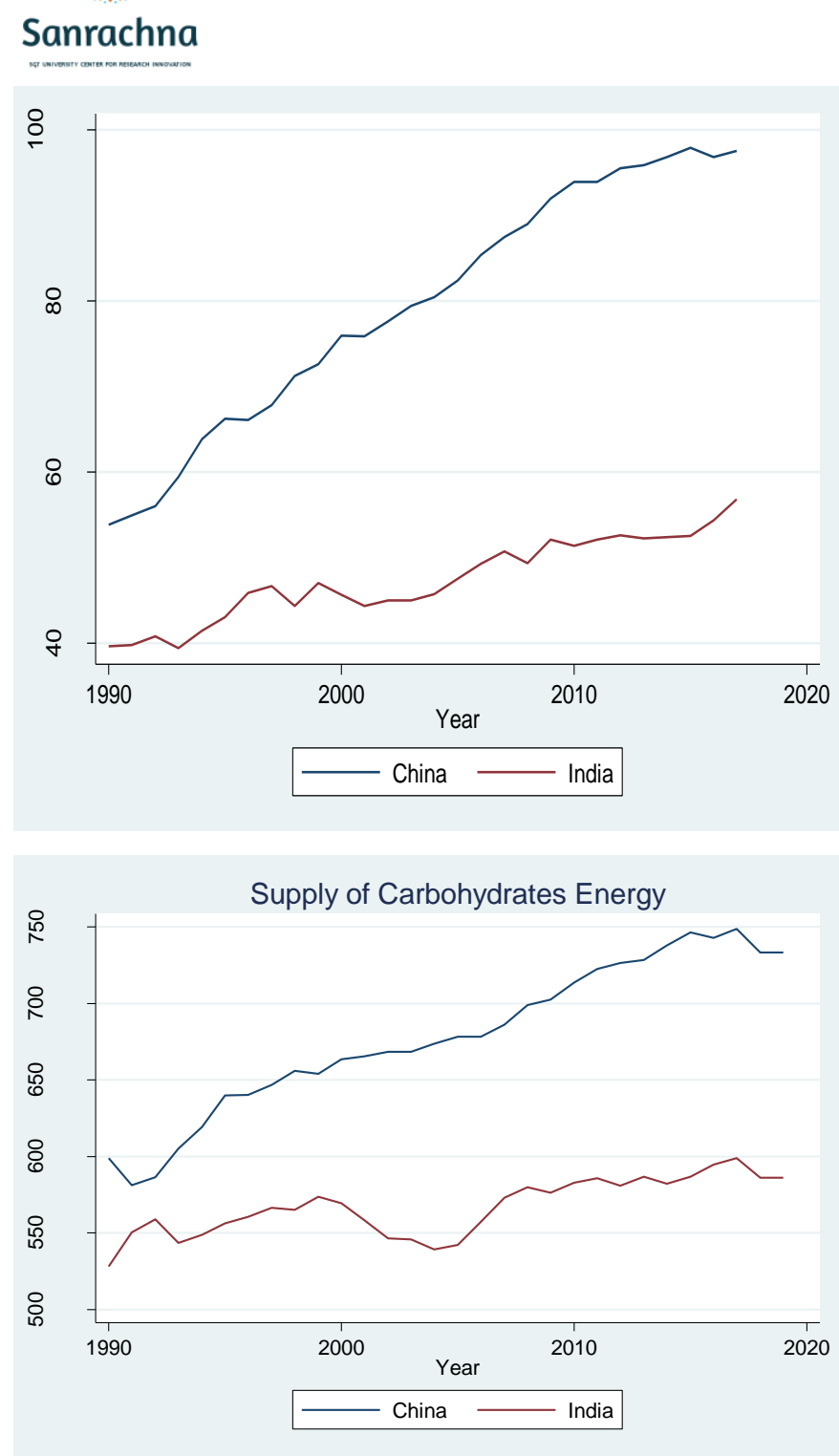

The graphs of energy from protein supply and fat supply, we can see that the trend is increasing for both countries but the rate is much higher in China than in India. In the starting of 1990s, the gap between protein supply and fat supply in both countries is narrow but with passing time the gap emerges to be increasing. As per shown in the graph only after 2010, the rate is increased for India in both cases. Energy from carbohydrates in both countries again follows the same pattern as protein and fat. However, in the case of India, the consumption of carbohydrates show a large dip between 2000 and 2010, after that it increases with fluctuations. In China, between 1990 and 2000, the consumption of carbohydrates increases at a high rate but after that, the increasing rate was not much high.

\section{Figure 12: The cereals consumption (kcal/capita/day) for China and India}




\section{Sanrachna}

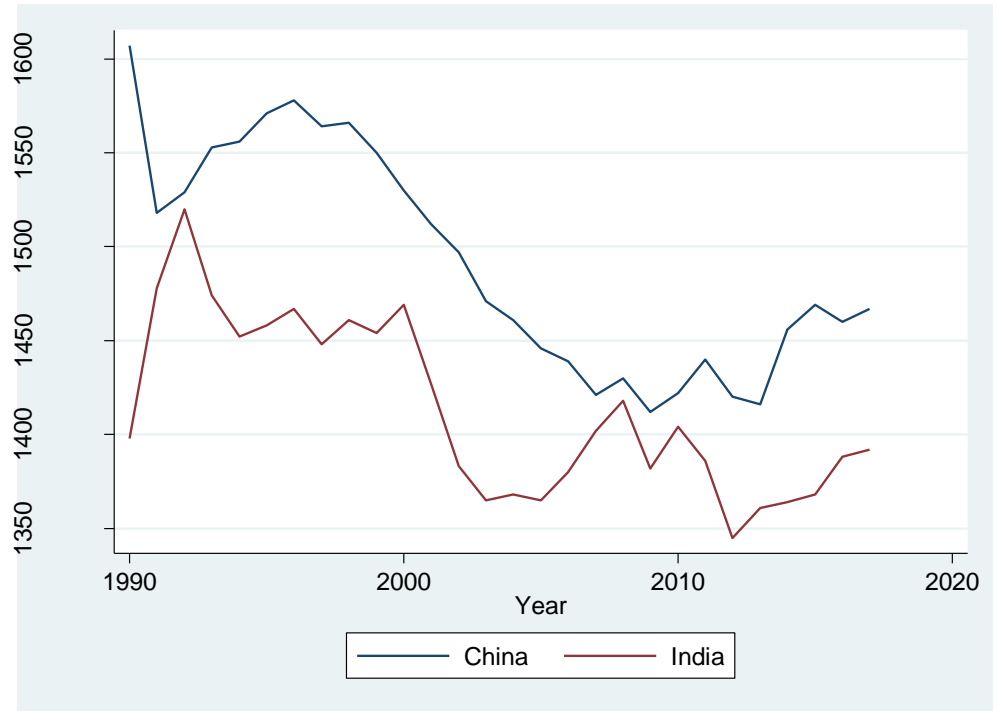

The consumption of cereals has a decreasing pattern for both India and China with fluctuation. The consumption of cereals in China is gradually decreased since the late 1990s but increased after 2010. Whereas in India the consumption is sharply fell after 2000 but it increased after 2010. The gap between the consumption of cereals in both countries becomes narrow in the late 2000s but after that, the trend is showing an increasing gap.

\section{Figure 13: Consumption of fruits (kcal/capita/day) in China and India}

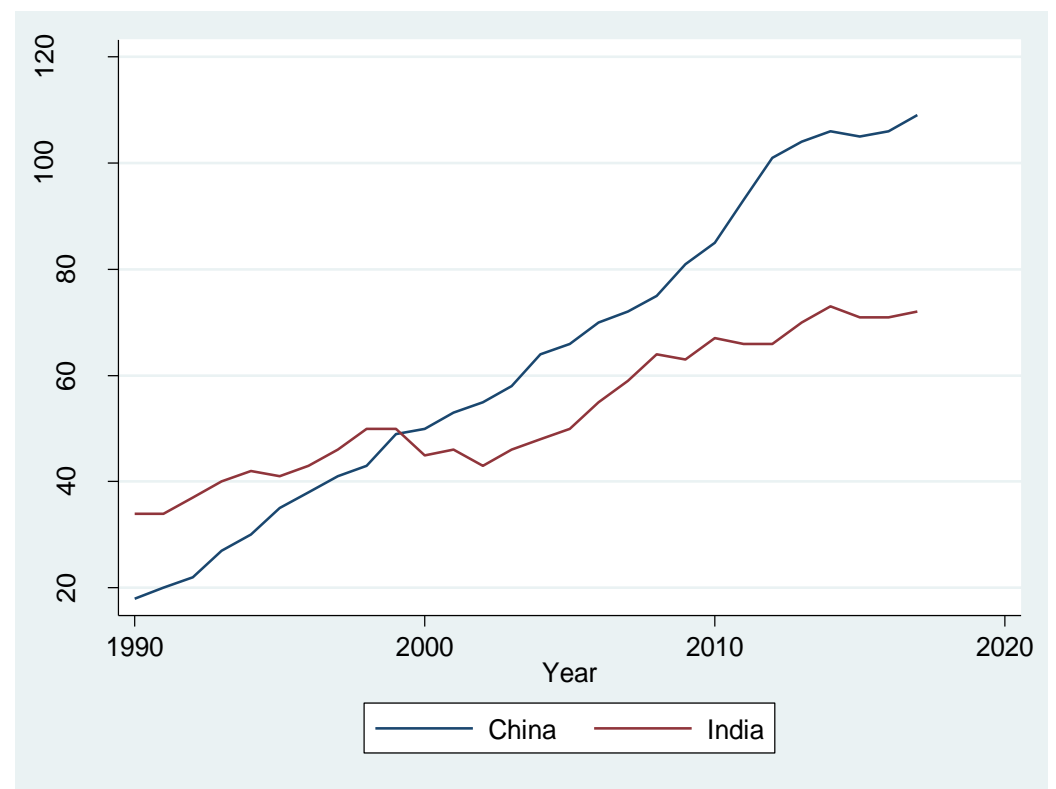

The trend in fruit consumption is increasing for both countries, however, the gap between two countries consumption is increased since the 2000s and in past few years, the fruit consumption is increased in China but not highly increase in India.

Figure 14: The consumption of sugar \& sweeteners (kcal/capita/day) for India and China 


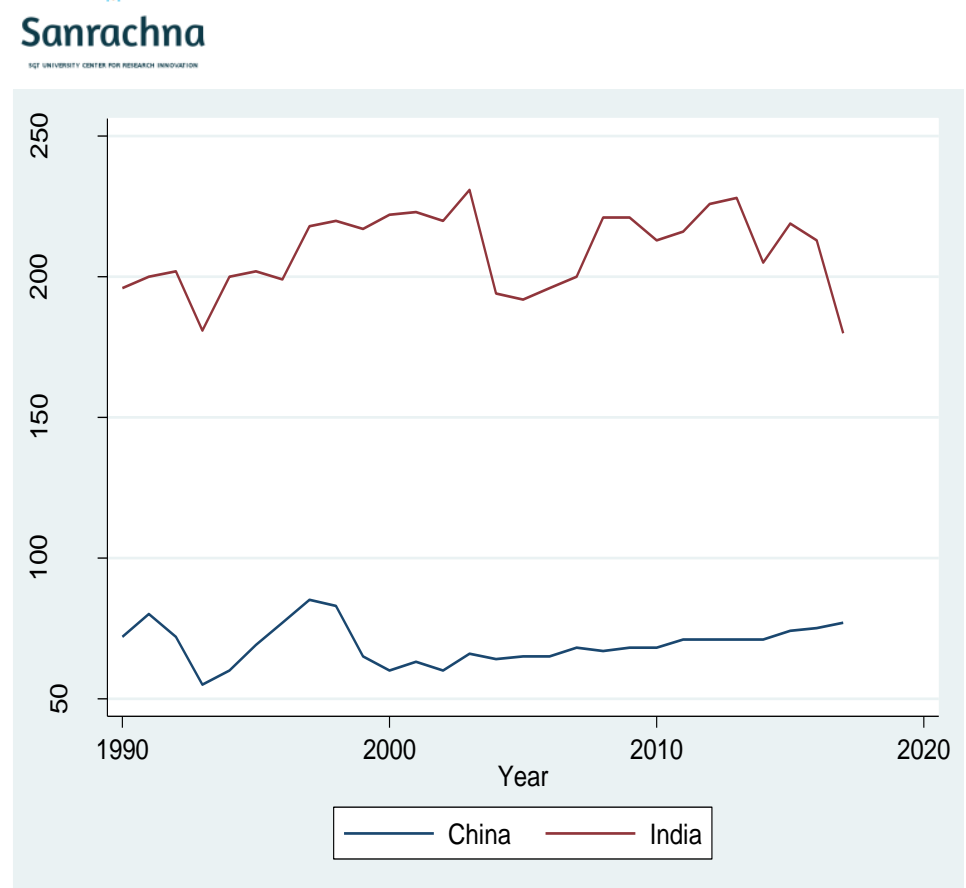

The consumption of sugar \& sweeteners (sugar, honey, and other sugar-made products) is high in India than in China. However, in India, it remains stable with fluctuation whereas, in China, the consumption of sugar \& sweeteners is increased at a lower rate since the 2000s.

\section{Figure 15: Consumption of vegetables (kcal/capita/day) for India and China}

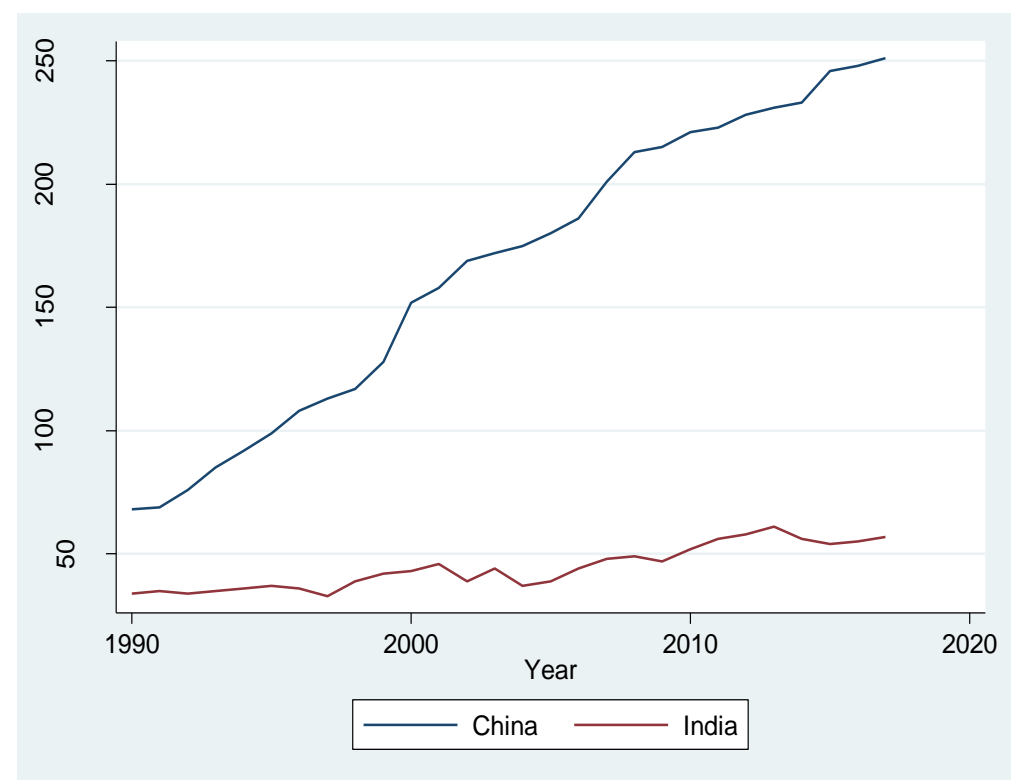

The consumption of vegetables is showing a divergence trend for India and China. In the early 1990s, the gap between the consumption of vegetables for both countries was very less but between 1990 and 2000 the vegetable consumption increased very fast in China whereas, in India, it was relatively stable. However, after 2000 the vegetable consumption increased in India also but relatively at a slower rate which shows the wide gap between both countries vegetable consumption. 


\section{Sanrachna}

Figure 16: The consumption of vegetable oil (kcal/capita/day) for India and China

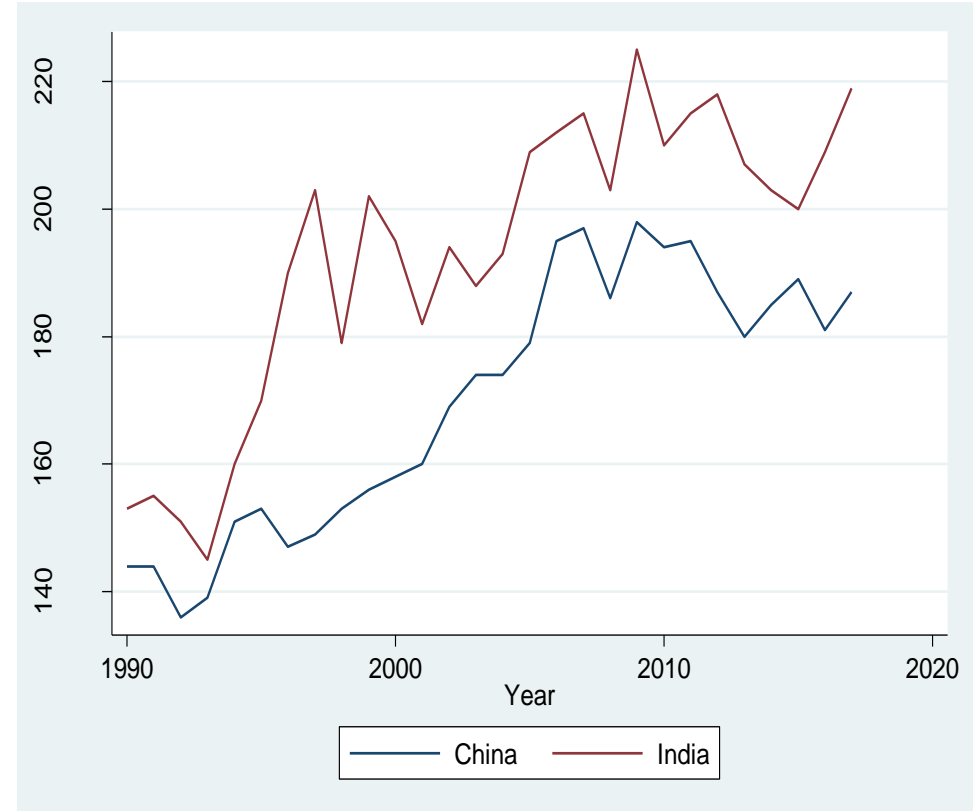

The overall trend of vegetable oil consumption is increasing for both India and China with fluctuation. However, the gap between both countries was very less in the early 1990s which become wide in the late 1990s and early 2000s and in the late 2000s the gap was decreased. However, in the mid-2000s China shows the fluctuation in vegetable oil consumption

\section{Figure 17: Consumption of animal fat (kcal/capita/day) for India and China}

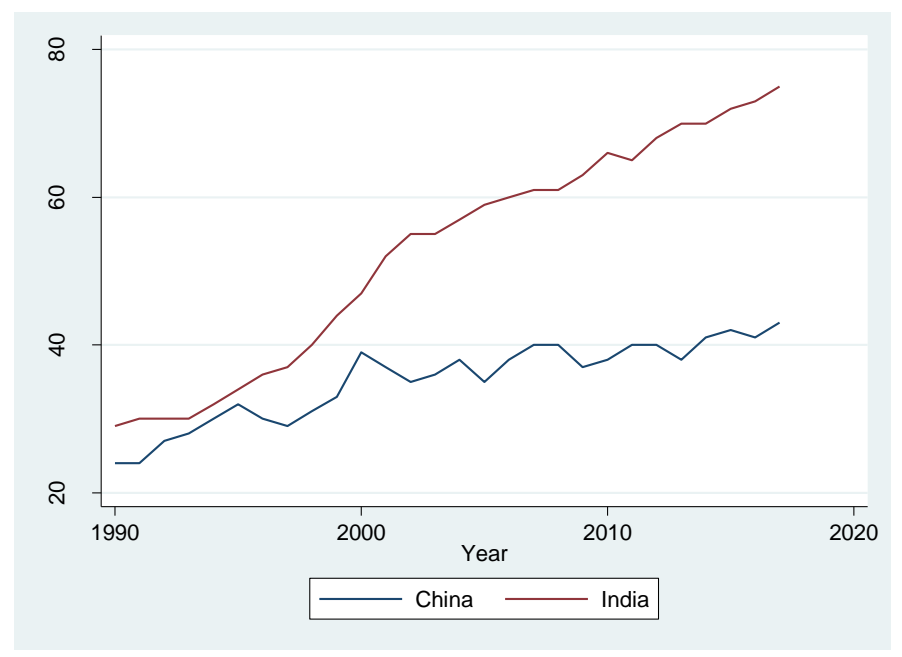

The overall trend for animal fat consumption is rising for both countries with some fluctuation in China however, in India the rise in animal fat consumption is high than in China.

Figure 18: Consumption of milk (kcal/capita/day) for India and China 


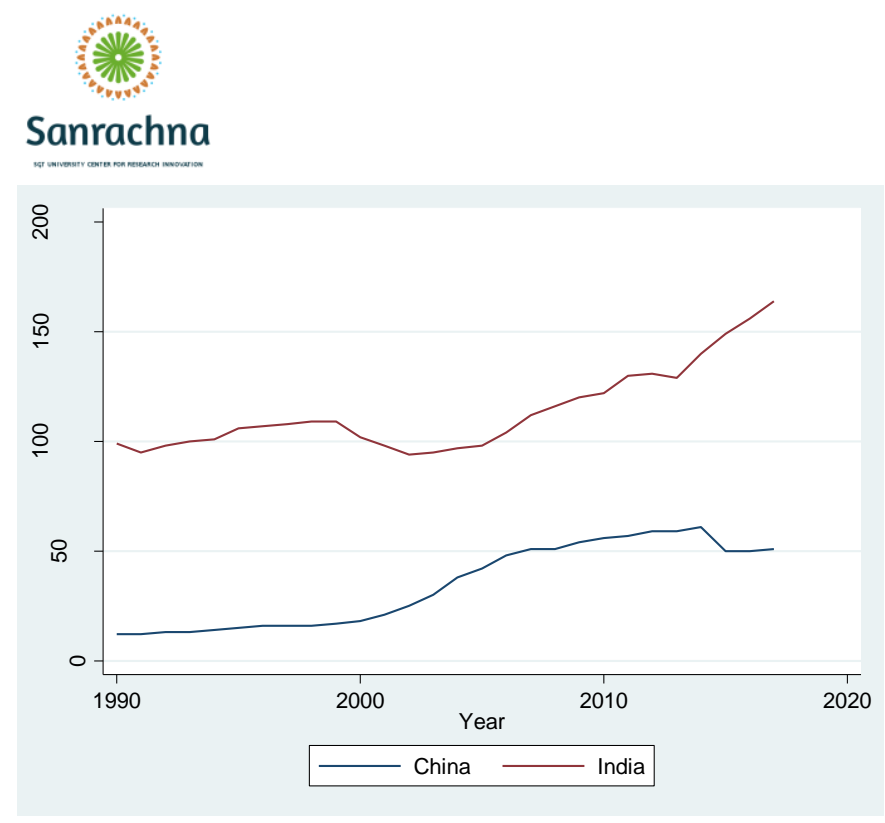

The milk consumption in China saw rapid rising after 2000 but after 2010 the rate of increase in milk consumption seemed to be quite slow. On the other hand, the consumption of milk saw some dip between 2000 and 2010 in India, after 2010, the milk consumption showed an increasing trend.

\section{Figure 19: Meat consumption (kcal/capita/day) for China and India}

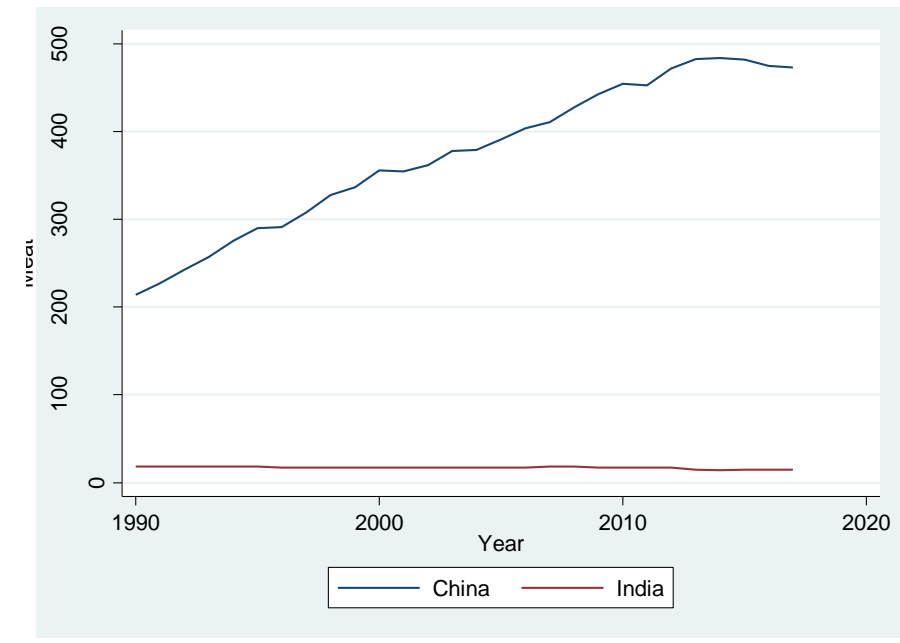

As shown by the above figure, the meat consumption is very much high in China however, after 2010, the meat consumption in China seems to be stable.

Figure 20: Pulses consumption (kcal/capita/day) for China and India 


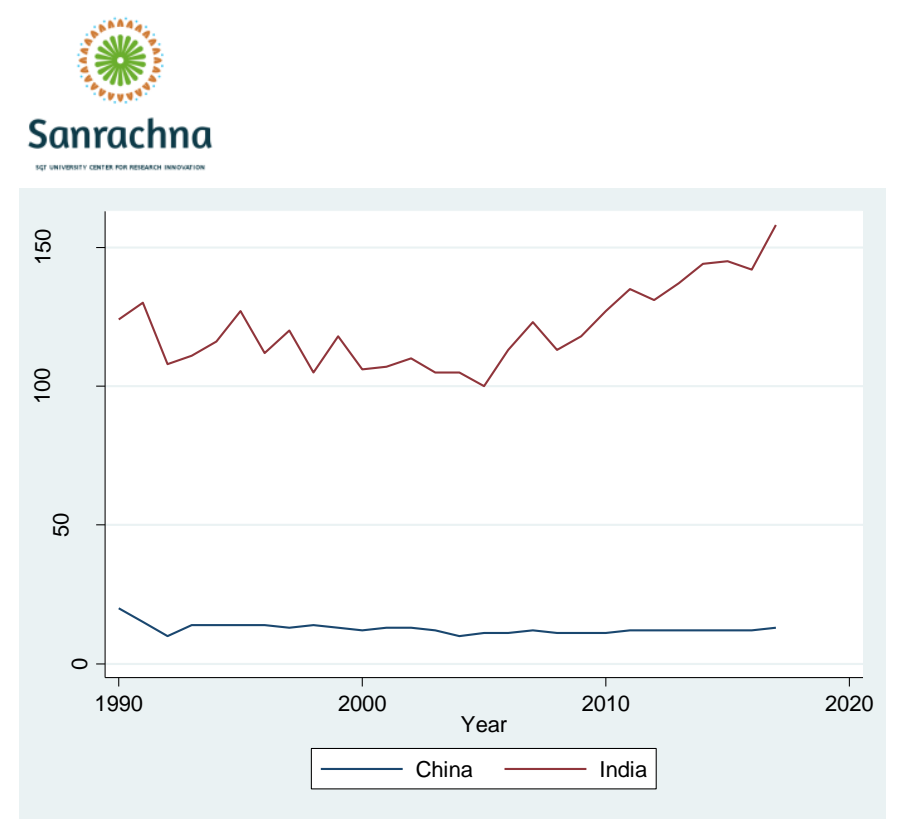

The consumption of pulses is obviously higher with fluctuation in India than in China, however, from 1990 to mid-2000s, the pulse consumption shows a decreasing trend for India and after that, it saw a rising trend.

The consumption of food groups containing carbohydrates such as milk, fruits, vegetables, and cereals shows increasing trends for both countries, however, the sugar and sweeteners show a reduction for India but show an increase for China. The consumption of food containing fat such as animal fat and vegetable oil shows a rising trend for both countries although the rise is higher for Indians than Chinese. Besides for protein supply, Indian consumes pulses while Chinese consumes meat however, the consumption of protein supply is found to be higher in China than in India.

\section{Conclusion}

The gap between the dietary pattern is found to be reduced globally. Consumption of many food groups shows convergence for a different region. Such as protein and calorie supply show a converging trend among low-income food deficit countries, least developed countries, and net food importing countries. The gap between industrialised countries and transition countries in per capita milk consumption is reducing. The trend of fat supply also shows that convergence between the European Community and North America. The supply of per capita vegetables also shows convergence for Europe, low-income food deficit countries and developing countries. However, the trend for per capita meat consumption shows that it is expected to diverge for East Asian Countries with average world consumption by 2030. However, many regions show a converging trend for different food groups but there can be much difference within the region and the countries. The consumption of macronutrients between India and China from 1990 to 2019 shows a converging trend in the early 1990s but after that, it shows divergence. A similar trend is also found with fruit consumption and animal fat consumption. The milk consumption between the two countries seems to converge from 2000 but after 2010 it shows diverging trends. In both countries, socio-economic factors push more toward carbohydrates diets. 


\section{Sanrachna}

\section{References}

Anon, FAO Study, Global and regional food consumption patterns and trends, Accessed from https://www.who.int/dietphysicalactivity/publications/trs916/en/gsfao global.pdf?ua=1

Anon, FAOSTAT, Food Balance, 2020, Accessed from http://www.fao.org/faostat/en/\#data

Anon, World Bank data, School enrolment, secondary, 2020, Accessed from https://data.worldbank.org/indicator/SE.SEC.ENRR

Anon, World Bank data, GNI per capita, 2020, Accessed from https://data.worldbank.org/indicator/NY.GNP.PCAP.KD

Anon, World Bank data, CPI, 2020, Accessed from https://data.worldbank.org/indicator/FP.CPI.TOTL

Anon, World Bank data, Urban Population (\% of total population), 2020, Accessed from https://data.worldbank.org/indicator/SP.URB.TOTL.IN.ZS

Alae-Carew, C., Bird, F. A., Choudhury, S., Harris, F., Aleksandrowicz, L., Milner, J., et al. (2019). Future diets in India: A systematic review of food consumption projection studies. Global Food Security, 23, 182-190. doi:10.1016/j.gfs.2019.05.006

Amarasinghe, Upali A., Shah, Tushaar, Singh, Om Prakash. (2007). Changing consumption patterns: implications on food and water demand in India. Colombo, Sri Lanka: International Water Management Institute (IWMI) 37p. (IWMI Research Report 119) doi: $10.3910 / 2009.119$

Bowen L, Ebrahim S, De Stavola B, Ness A, Kinra S, Bharathi A, et al. (2011) Dietary Intake and Rural-Urban Migration in India: A Cross-Sectional Study. PLoS ONE 6(6): e14822. https://doi.org/10.1371/journal.pone.0014822

Cui, Z., \& Dibley, M. J. (2012). Trends in dietary energy, fat, carbohydrate and protein intake in Chinese children and adolescents from 1991 to 2009. British Journal of Nutrition, 108(07), 1292-1299. doi:10.1017/s0007114511006891

Choudhury, S., Shankar, B., Aleksandrowicz, L., Tak, M., Green, R., Harris, F., et al. (2020). What underlies inadequate and unequal fruit and vegetable consumption in India? An exploratory analysis. Global Food Security, 24, 100332. doi:10.1016/j.gfs.2019.100332

Drewnowski, A., \& Popkin, B. M. (1997). The Nutrition Transition: New Trends in the Global Diet. Nutrition Reviews, 55(2), 31-43. doi:10.1111/j.1753-4887.1997.tb01593.x

Du, S. F., Wang, H. J., Zhang, B., Zhai, F. Y., \& Popkin, B. M. (2013). China in the period of transition from scarcity and extensive undernutrition to emerging nutrition-related noncommunicable diseases, 1949-1992. Obesity Reviews, 15, 8-15. doi:10.1111/obr.12122 


\section{Sanrachna}

Government of India, National Action Plan for Egg \& Poultry - 2022 for Doubling Farmers' Income by 2022, Department of Animal Husbandry, Dairying \& Fisheries, Ministry of Agriculture \& Farmers Welfare. Accessed from http://www.dahd.nic.in/sites/default/filess/Seeking\%20Comments\%20on\%20National\%20Action\%2 OPlan-\%20Poultry-\%202022\%20by\%2012-12-2017.pdf

Huang, L., Wang, Z., Wang, H., Zhao, L., Jiang, H., Zhang, B., \& Ding, G. (2020). Nutrition transition and related health challenges over decades in China. European Journal of Clinical Nutrition. doi:10.1038/s41430-020-0674-8

Kammlade, S. et al. (2017), The changing global diet - country comparison, CIAT, Accessed from https://ciat.cgiar.org/the-changing-global-diet/country-comparison/

Kaicker et al. (2011), Dietary transition in India: An Analysis based on NSS data for 1993 and 2004, ASARC Working Paper 2011/10, Accessed from https://cnnd.crawford.anu.edu.au/acde/asarc/pdf/papers/2011/WP2011 10.pdf

Kumar, P., Joshi, P.K., and Birthan, P.S. (2009), Demand projection for foodgrains in India, Agricultural Economics Research Review Vol. 22, pp 237-243

Liu, D., Zhao, L.-Y., Yu, D.-M., Ju, L.-H., Zhang, J., Wang, J.-Z., \& Zhao, et al. (2018). Dietary Patterns and Association with Obesity of Children Aged 6-17 Years in Medium and Small Cities in China: Findings from the CNHS 2010-2012. Nutrients, 11(1), 3. doi:10.3390/nu11010003

Morreale, J.C., Shostya, A., \& Villada, M. (2018). China's rising middle class: A case study of Shanghai college students. Journal of International Studies, 11(2), 9-22. doi:10.14254/2071$8330.2018 / 11-2 / 1$

Mishra et al. (2011), Nutrition transition in India: Secular trends in dietary intake and their relationship to diet-related non-communicable diseases, Journal of Diabetes, https://doi.org/10.1111/j.1753-0407.2011.00139.x

Minocha, S., Makkar, S., Swaminathan, S., Thomas, T., Webb, P., Kurpad, A.V., (2019), Supply and demand of high quality protein foods in India: Trends and opportunities, Global Food Security, vol.23, pp 139-148, doi: https://doi.org/10.1016/j.gfs.2019.05.004

OECD (2020), Meat consumption (indicator). doi: 10.1787/fa290fd0-en (Accessed on 21 July 2020)

OECD (2020), Young population (indicator). doi: 10.1787/3d774f19-en (Accessed on 21 July 2020)

Popkin, B. (2001), The nutrition transition and obesity in developing world, The Journal of Nutrition, Volume 131, Issue 3, March 2001, Pages 871S-873S, doi https://doi.org/10.1093/jn/131.3.871S 


\section{Sanrachna}

Popkin, B., Horton, S., Kim, S., Mahal, A., and Shuigao, J. (2001), Trends in diet, nutritional status, and diet-related noncommunicable diseases in China and India: the economic costs of the nutrition transition, Nutrition Review, 59(12):379-90. doi: 10.1111/j.17534887.2001.tb06967.x.

Roy, A. (2018), The middle class in India from 1947 to the present and beyond, Education about Asia, Asian Politics, 23(1)

Sharma, M., Kishore, A., Roy, D., and Joshi, K., (2020), A comparison of the Indian diet with the EAT-Lancet reference diet, BMC Public Health, 20(1):812. doi: 10.1186/s12889020-08951-8.

Su, C., Zhao, J., Wu, Y., Wang, H., Wang, Z., Wang, Y., \& Zhang, B. (2017). Temporal Trends in Dietary Macronutrient Intakes among Adults in Rural China from 1991 to 2011: Findings from the CHNS. Nutrients, 9(3), 227. doi:10.3390/nu9030227

Su, C., Song, X., Hu, H., Du, W., Wang, H., \& Zhang, B. (2020). Longitudinal Association between Urbanicity and Total Dietary Fat Intake in Adults in Urbanizing China from 1991 to 2015: Findings from the CHNS. Nutrients, 12(6), 1597. doi:10.3390/nu12061597

Tak et al. (2019), Dietary transition in India: Temporal and Regional Trends, 1993 to 2012, Food and Nutrition Bulletin, https://doi.org/10.1177/0379572119833856

Xu, X., E. Byles, J., Shi, Z., \& J. Hall, J. (2015). Evaluation of older Chinese people's macronutrient intake status: results from the China Health and Nutrition Survey. British Journal of Nutrition, 113(01), 159-171. doi:10.1017/s0007114514003444

Yunzi et al. (2018), Analysis of dietary trend in Chinese adolescents from 1991 to 2011, Asia Pac J Clin Nutr; 27(5), pp. 1106-1119. doi: 10.6133/apjcn.042018.02

Zhao, J., Su, C., Wang, H., Wang, Z., Wang, Y., \& Zhang, B. (2018), Secular Trend in Energy and Macronutrient Intakes and Distribution among Adult Females (1991-2015): Results from the China Health and Nutrition Survey. Nutrition, 10(2):115, doi: 10.3390/nu10020115.

Zhai, F., Wang, H., Du, S., He, Y., Wang, Z., Ge, K., \& Popkin, B. M. (2009). Prospective study on nutrition transition in China. Nutrition Reviews, 67, S56-S61. doi:10.1111/j.17534887.2009.00160.x

Zhai, F. Y., Du, S. F., Wang, Z. H., Zhang, J. G., Du, W. W., \& Popkin, B. M. (2014). Dynamics of the Chinese diet and the role of urbanicity, 1991-2011. Obesity Reviews, 15, 1626. doi:10.1111/obr.12124 